\begin{tabular}{|c|}
\hline Asian Social Work Journal (ASWJ) \\
$\substack{\text { ASAN SOCIAL WORK } \\
\text { JOURAL } \\
\text { (ASW) }}$ \\
\end{tabular}

\title{
Parenting Support Communication Model Development Using Whatsapp Messenger in TK Islam Mutiara Hikmah Dan Lalita Kita Bintaro
}

\author{
Lilik Sumarni ${ }^{1}$, Annisa Putri Larasati ${ }^{1}$, Daniel Handoko ${ }^{1}$ \\ 1University of Muhammadiyah Jakarta, Indonesia \\ Corrrespondence: Lilik Sumarni (liliksumarni@umj.ac.id)
}

\begin{abstract}
Parenting for early childhood should be prioritized due to the importance of both physical and psychological aspects of children's growth and development. A parenting model accompanied by parents, teachers and also psychological experts will result the balance oh physical and psychological health of the children. The development of social media like WhatsApp Messenger which has not been used optimally for parenting support socialization could be mentioned as an unfortunate chance. Due to that matter, the purpose of this research, thus: to describe the existing communication flow between parents and the school of TK Islam Mutiara Hikmah dan TK Lalita Kita Bintaro, to describe the result of parenting support model development in the teachers' and parents' behavior, and to find supporting and challenging factors to the communication development of the parenting model support that uses the WhatsApp Messenger. Methodology used in this research is descriptive methodology by the qualitative approach. Furthermore, the informants are invited by purposive and accidental methods. The informants consisted of two educators at TK Mutiara Hikmah, two psychologists from both schools, two educators at TK Lalita Kita Bintaro, eight students' guardians from TK Mutiara Hikmah and nine students' guardians from TK Lalita kita Bintaro. Data collection is conducted by doing indepth interviews, documentations, and observation. The data analysis technique is conducted by using qualitative analytical method and descriptive method periodically since the beginning of data collection to the end of the research. To create the meaning of concluded data, researchers did the data analysis and the interpretation. The validity of data is tested by implementing source triangulation. Research output is to develop the communication model of parenting support by using WhatsApp Messenger. Theoretical basis used in this research is Osgood and Schramm's Circular Communication Model. This model of communication is laid on the understanding that communication is conducted by two sides. Osgood explains that communication exists circularly rather than in linear way. The research is done for 6 months from January 25-July 25 2018. The results show: 1. The description of communication flow between teachers and parents has not been carried out in significant way since there are many parents working. Thus, the researchers tried to develop the communication model for parenting support by using WhatsApp Messenger to ease the more interactive communication for working parents. Furthermore, the use of social media could also ease the delivery of parenting support materials such as, curriculums, school's subjects, and the announcements so that more dynamical communications with feedback can exist. 2. The result of parenting support model development is the coordination of the parenting support program can be done easier and optimally for those who already have the WhatsApp Messenger account. The delivery of materials and discussions via WhatsApp Messenger gives solution for parenting support problem. Significant results are as follow: a. Parents got helped by sharing activities via WhatsApp Messenger, b. Those materials shared via WhatsApp made children more independent and easier to control the psychological development, c. Children get braver at school and hyperactive children get calmer, d. Facilitating the problem solving process, e. Changing of children's behavior such as, communication skills, concern feelings, and getting more method of learning and playing based on the ages, f. Raising concern for parents about all aspects of children's
\end{abstract}


growth and development, g. Giving more knowledge of parenting to parents by visualizing it through videos and variative tutorials. Supporting and challenging factors to the development of communication model via WhatsApp Messenger are as follow: internet connection service, financial problem of parents to provide the facilities and phycologists, schools' poor facilities and infrastructures, and poor parents' role since they are working are the challenging factors. While supporting factors are parents' concern, internet connection, dynamic discussion between parents and teachers so that parents could easily implement the materials at home, and facilities provided by school, teachers' concerns to children's psychological development. Communication flow between parents and teachers has not been conducted optimally even though WhatsApp Messenger was already used by them, this model is positively reacted by the school and parents, and also, the benefits are considered directly. Furthermore, significant factors for the success of this model is human resources, facilities and infrastructure, and financial problems.

Key words: communication model, parenting support, whatsapp messenger

\section{Introduction}

The understanding of exchanging information is not limited by place and time anymore or, by the meeting of information sender and accessor in one same place and time. All of those have high possibility to happen since the development of communication technology is rapidly sped up. This thing becomes undoubted due to the more dynamical humans' needs. These dynamics is the reflection of humans' very complex dimension. One of them is that human as social animal who use media to establish the social relations (Suharsimi, 2017).

New media and technology have given us new tools and ways to gain information and ideas, interact with friends and foreigners, and to learn about the world, our identities and the future (Gamble, 2005 in Nursalim, 2017). Millions of people now are interacting through what is called cyberspace that is a world connected by mobile phones and the internet. By using the 'new' media, social media is introduced. Social media became one of the most important media since its presence that gives massive change into the process of sending messages. Nowadays, people are commonly using internet and social media to communicate (Nursalim, 2017).

Social media has positive functions, those are; a) to give information about events and the condition of the society; to ease the creation of innovation, adaption and progress, b) to give explaining and interpreting information, to comment the meaning of events and information; to create consensus by socializing, c) to give information related to continuation including the increasing and preservation of values, d) to entertain in order to ease social tension and to become a relaxation facility, e) to mobilize society in political and developmental field (McQuil, 1996 in Nursalim, 2017).

The amount of internet user in Indonesia during 2016 is 132.3 million users or about \%51.5 out of the total of Indonesian population that is 256.2 million people (APJII, 2016 in Fernando, 2017).

Meanwhile, the role position of family as the smallest unit in the society has prior and main responsibility in maintaining children's growth dan development. A child will grow and develop optimally if the basic needs that become the child's rights can be fulfilled. Meanwhile the basic needs of children are physical needs (such as food and clothing) and psychological needs (such as, support, attention and affection) (Rohinah, 2016). The role of family in educating children gives positive impression to the development indirectly, one of the results is seriousness in learning activities besides showing off the better and balanced behaviors (Hayati and Mamat, 2016).

Thus, there are a big amount of negative impacts of the communication and information development which has changed the order of humans' life, making it far from local values caused by the inability to control the content of internet, in this case, social media. It is the time for parents to get involve directly in parenting not only leaving educating responsibilities to teachers at school. Social media is proven 
significantly as communication tool which should be utilize as dialogic educating facility between teachers and parents to educate the children especially early aged - children.

Amini and Prastito (2013) said that to optimize the meeting of parents and teachers in educating the children it is needed a tool to facilitate the parenting program from different place and time. The characteristics owned by social media should help parents and teachers to connect each other by creating a group via social media account. It is shown that Whatsapp Messenger is easily accessible by the users to communicate mutually or discuss about the education or learning programs at school.

\section{Methodology}

The methodology used in this research is descriptive qualitative that is implemented by creating a discussion group (focus discussion group) using social media account, that is, Whatsapp Messenger. Whatsapp Messenger is completed by media sharing features that allow teachers to send materials or information about happening activities or future activities at school. Furthermore, it is easily accessible by the parents.

Data analysis is conducted at the same time, that is by the collecting of raw data, for example, interviews, observation and literature review. In this stage, it was needed tools like voice recorder, camera and others. The data is recorded the way it is. It is not allowed to mix it with opinions or researchers' attitudes.

Data transcripts are also described as they were recorded in the interviews. Meanwhile triangulation is a rechecked finding by using validity checking techniques and extending research time by using triangulation technique. Triangulation that is used here is the source triangulation that is interviewing variative sources until the result is reaching the saturation point.

Premiere data source is gained by doing observation and interviews. Observation used by the researchers is open observation where researchers explaining openly to the sources that the researches is in the middle of conducting research. Therefore, the parties being dragged into the research know all the process since the beginning until the end of the research.

Secondary data source is gained by literature study and documentation study. The results of literature study are gained from different references such as textbook or scientific journals. Meanwhile the documentation study is gained from the official documents related to the matters of the research.

\section{Population and Sample}

The object in this research is the Implementation of Parenting Support Program at the School of TK Mutiara Hikmah and TK Lalita Bintaro in Ciputat. The information is gained by doing purposive sampling, that is a method to determine the samples based on certain characters related to the needs. To determine the informants in qualitative research is to get key informants based on the research focus. While, secondary informants are used as alternative way for researchers who could not determine participants directly. In this research, the informants are all parties involving in the Effectivity of Parenting Program Implementation at those two kindergartens. The key informants are the headmasters, teachers and students' guardians. The population of this research are parents having children under 5 years old who are included into Early Childhood Education Program (ECEP). In this research, researchers used accidental sampling that is based on findings by chance. Those are parents having children included in ECEP who already understand the technology of social media.

\section{Results and Discussion}

Communication Flow and the Result of Parenting Support Communication Model Development by Using WhatsApp Messenger 
The existing communication flow held by the schools was conducted by discussion and parents meeting, the usage of social media and phone is only as general informing tool. It was not used for materials delivery related to parenting support. The interviews showed that the communication flow between teachers and parents has not been conducted optimally. Nevertheless, the schools tried to hold meetings or discussions directly to talk with parents. Thus, researchers develop a method in communication model using social media that is WhatsApp Messenger. It is familiar to be used for communication between teachers and the parents. However, this development is wished to increase the utilization optimally.

The benefits of social media is not only for discussing problem solving, but also to share information related to socialization and updated parenting education by all the teaching staffs.

The materials about parenting methods shared in via social media, especially the solution recommended by psychologists in this case, help the accompaniment for children if they face difficulties to socialize and to adapt with the environment. That method helps parents to stimulate the children behaviors directly at home. It is show by variety of progress such as, more independent children; dressing up by him/herself; eating by him/herself; and the most important thing is children is not afraid to spent their days at school. Psychological aspects in educating children is important too since in early age children pass the stage of introduction and learning.

According to Henderson and Mapp (200) in Amini and Prastito (2013), it is proven that parents' engagement in educating children is linear to children's achievements, behaviors, cultures, ages and the school's quality. In achieving, the influence of parent's engagements are as follows: (1) when parents get engaged-without seeing socio-economic situation and status, background, race, or educationchildren tend to be having more achievements, (2) children will be more helpful to parents at home, and presence at school is higher. (3) achievements of children form needy family is higher, it is also getting higher to the standard of middle-class family, (4) children most likely to have decreasing of achievements if parents do not get engaged in school activities or relations with teachers.

The understanding of children's development is an important factor that parents should have to optimize the potential children. Catron and Allen (1999) in Hayati (2011), said that there are six aspects of children's development, those are, personal concern, emotional health, socialization, communication, cognition and motoric skills. The understanding towards children's developments can be concluded as cognitive aspects or intellectuals, physical-motoric, language, socioemotional, and moral values.

Epstein (1995) in Amini and Prastito (2013) identified six types of parents' involvement and strategy that teachers can do to develop cooperation with parents. They are parenting, communicating, volunteering, learning at home, decision making, and collaborating with community.

If these six strategies being implemented to the context of TK Mutiara Hikmah and TK Kita Lalita Bintaro, it is to develop the cooperation between school and parents. Firstly, parenting; introduces the parenting program and accompaniment to the children fitting the needs of the children based on the psychological aspects and understanding ability. Secondly, communicating; by using alternate communicative media that is social media so that communication between school and parents could be conducted dialogically and there would be direct feedback, so that harmonic communication can create emotional bonding.

Thirdly, volunteering, that is teacher and parents get engage into the communication without any force from any parties. The next strategy is learning at home, that is, giving support to the children and implement the education into behaviors or doing daily activities. After that is decision making, that is, training the children to be braver in making decision or taking choice so that children will be more confident. The sixth is collaborating with community, that is, parents can introduce environments to their children and teach how they should behave to those environments. Besides, parents can show children how to appreciate their own selves by being positive to others, and having empathies. 
Some of ECEP (Early Childhood Education Program) based on family can be taken by the schools. One of them is periodically supported parenting class. Parenting class can be defined as a communication platform for parents or family to share information and knowledge in educating 0-6 years old children. The aim is to rise the awareness, knowledge, attitude and skills of parents to operate the ECEP in the family environments.

The types of parenting class activities are: sharing opinions, workshop, simulation, or learning certain skills. This kind of parenting class should be started by analyzing the needs including: the understanding of parents about children, parents' expectation to their children, parenting at home, children's nursing at home, nutritious feeding at home, education simulation and children protection (Dit. PAUD, 2012).

The material delivery by the schools should be procedural including started by collecting issues based on parents' claims. This kind of problem solving should involve psychologists as expert parties in the field. After the issues are identified well, parents could be invited. The meetings will be held in every beginning of academic year. Other time can be added to socialize the program.

Social media is understood as a group of online media, divided into 5 characteristics: (1) Participations. Social media encourages contributions and feedback (Suyuti in Arsyad, 2011). (2) Openness. Social media is open to feedback and participation, encouraging voting, comment and information sharing. (3) Conversation. Not like traditional media, social media allows us communicate mutually. (4) Community. Social media allows us to create community quickly and effectively communicate. (5) Connectivity. Social media uses link into other sites, resources and people inside it (Lester Voit in Sindang, 2014).

One of benefits in using Technology and Information tools to access social media is the ability to interact and share. Users are challenged to allocate times and energy to realize those thigs (Selwyn, 2009 in Sukmana 2016). If we implement into the analysis by using the theory above it will show that WhatsApp as one of media choices to connect parents and teachers in parenting program, it is because of its characteristics.

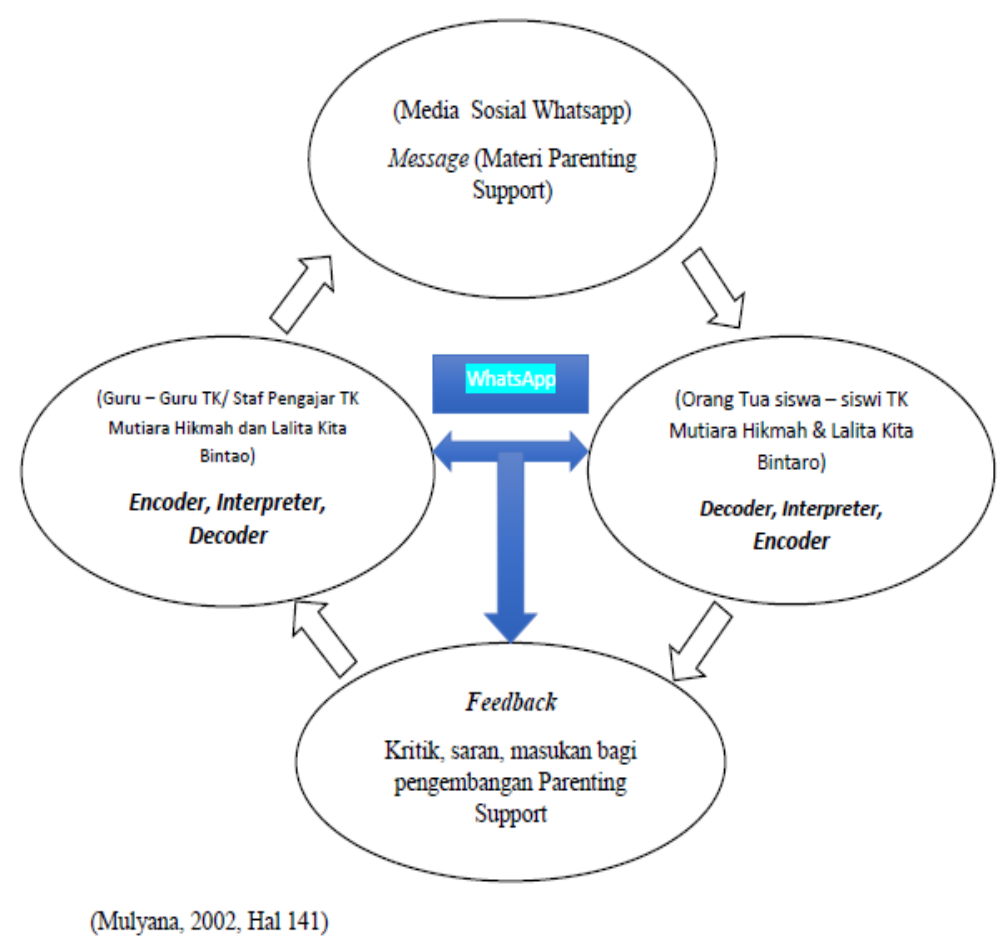

Figure 1. Parenting Support Communication Model by Using WhatsApp Messenger in TK Islam Mutiara Hikmah and Lalita Kita Bintaro. 
In the message of implementation of Circular Communication Model by Osgood and Schramm, parenting support has resulted an interpersonal and dialogic communication flow simultaneously. In this case, teachers and parents are the communicators that encode messages and information in the form of news, materials and discussions to find solution. The media is social media, that is WhatsApp. It is implemented to the parents as the persons who decode the messages and information. They will respond and give feedback in the form of critics, suggestion and other contributions.

\section{Conclusion}

Description of communication flow between parents and teachers in TK Mutiara Hikmah and TK Lalita Kita Bintaro has not been done significantly since there are a lot of working parents. Teachers already invite parents for meeting. Communications are also using WhatsApp Messenger. But this research is wished to have the development to the model of communication so that the utilization of the social media is optimal.

It is realized that the result of this model development is the well-coordinated programs for parenting. The social media is also easier to be used so that parents can access the materials quickly. Parents skills and knowledge about parenting is updated by this kind of communication.

Significant results are as follow: a. Parents got helped by sharing activities via WhatsApp Messenger, b. Those materials shared via WhatsApp made children more independent and easier to control the psychological development, c. Children get braver at school and hyperactive children get calmer, d. Facilitating the problem solving process, e. Changing of children's behavior such as, communication skills, concern feelings, and getting more method of learning and playing based on the ages, f. Raising concern for parents about all aspects of children's growth and development, g. Giving more knowledge of parenting to parents by visualizing it through videos and variative tutorials.

Supporting and challenging factors to the development of communication model via WhatsApp Messenger are as follow: internet connection service, financial problem of parents to provide the facilities and phycologists, schools' poor facilities and infrastructures, and poor parents' role since they are working are the challenging factors. While supporting factors are parents' concern, internet connection, dynamic discussion between parents and teachers so that parents could easily implement the materials at home, and facilities provided by school, teachers' concerns to children's psychological development.

Based on the findings in the field, researchers want to deliver these recommendations to both schools:

i. Awareness and understanding is needed by parents to complete their roles for maintaining children's growth and development so that it is not only school's task.

ii. Providing facilities and infrastructures.

iii. The optimization of social media usages.

iv. Human resources especially teachers should have better knowledge about parentings.

v. Media literation is a significant factor for using social media. It is important to socialize how to use the social media carefully and for education purposes only. Workshop and training can be done periodically.

\section{References}

Arikunto, Suharsimi dan Safrudin, Cepi, 2009, Evaluasi Program Pendidikan : Pedoman Teoritis Praktis bagi Mahasiswa dan Praktisi pendidikan; Jakarta, Bumi Aksara.

Afrilia, A. M. (2017). PENGGUNAAN NEW MEDIA DI KALANGAN IBU MUDA SEBAGAI MEDIA PARENTING MASA KINI. Jurnal Komunikasi dan Kajian Media, 1(1), 31-42. 
Amini, M. (2015). Profil Keterlibatan Orang Tua dalam Pendidikan Anak Usia TK. JIV-Jurnal Ilmiah Visi Pembinaan Pendidik dan Tenaga Kependidikan Pendidikan Anak Usia Dini, Nonformal dan Informal, 10(1), 9-20.

Amini, M., \& Pratisto, T. (2013). Pengembangan Model 'Parenting Class' Pada Pendidikan Anak Usia Dini (PAUD) Untuk Meningkatkan Keterlibatan Orang Tua Dalam Mendidik Anak.

Stanley J. Baran, Dennis K.Davis, 2010. Mass Communication Theory: Faoundations, ferment and Future, Belmot: CA, Wadswoth.

Badu, R. (2011). Pengembangan Model Pelatihan Permainan Tradisional Edukatif Berbasis Potensi Lokal dalam Meningkatkan Kemampuan dan Keterampilan Orang Tua Anak Usia Dini di PAUD Kota Gorontalo. Jurnal Penelitian dan Pendidikan, 8(1), 70-77.

Diadha, R. (2015). Keterlibatan orang tua dalam pendidikan anak usia dini di taman kanak-kanak. Edusentris, 2(1), 61-71.

Dini, D. P. P. A. U. (2012). Pedoman Penyelenggaraan Pendidikan Anak Usia Dini Berbasis Keluarga.

Fernando, D. (2017). Potensi Keuntungan Kompetitif Penggunaan Internet Bagi Perusahaan. JSiI (Journal Sistem Informasi), 3.

Hayati, F., \& Mamat, N. (2016). Pengasuhan dan Peran Orang Tua (Parenting) serta Pengaruhnya Terhadap Perkembangan Sosial Emosional Anak di PAUD Banda Aceh, Indonesia. Jurnal Buah Hati, 1(2).

Hayati, N. (2011). Peran orang tua dalam pendidikan anak usia dini.

Imam-Tobroni, S. (2001). Metodologi Penelitian Sosial-Agama.

Lim, M. (2017). Klik yang Tak Memantik: Aktivisme Media Sosial di Indonesia. Jurnal Komunikasi Indonesia, 35-50.

Mulyana, Deddy, 2002, Ilmu Komunikasi Suatu Pengantar, Bandung: Remaja Rosdakarya.

Moleong, Lexy J (2005), Metodologi Penelitian Kualitatif. Bandung: Remaja Rosdakarya.

Ningrum, A. K. (2016). Parenting self efficacy pada ibu bekerja dengan anak usia pra-sekolah (Bachelor's thesis, UIN Syarif Hidayatullah Jakarta: Fakultas Psikologi, 2016).

Nursalim, M. (2017). PERAN KONSELOR DALAM MENGANTISIPASI KRISIS MORAL ANAK DAN REMAJA MELALUI PEMANFAATAN MEDIA “BARU”. Bikotetik (Bimbingan dan Konseling: Teori dan Praktik), 1(2), 59-65.

KPPPA (Kementrian Pemberdayaan Perempuan dan Perlindungan Anak RI); Pedoman Penanganan Anak Dengan Kesulitan Belajar Khusus. 2015

Rostiana, I., Wilodat, W., \& Alya, M. N. (2015). Hubungan Pola Asuh Orang Tua Dengan Motivasi Anak Untuk Bersekolah Di Kelurahan Sukagalih Kecamatan Sukajadi Kota Bandung. Sosietas, $5(2)$.

Sugiyono, M. P. P. (2007). Pendekatan Kuantitatif. Kualitatif, dan R\&D, Bandung: Alfabeta.

Suharsimi, A. (2006). Prosedur penelitian suatu pendekatan praktek. Jakarta: Rineka Cipta.

Sindang, E. (2014). Manfaat Media Sosial dalam Ranah Pendidikan dan Pelatihan. Pusdiklat KNPK.

Teviani, D. (2017). Fenomena Pengguna Whatsapp Di Kalangan Mahasiswa Kota Bandung (Doctoral Dissertation, Perpustakaan 